\title{
Darwin and the Tree of Life: the roots of the evolutionary tree
}

\author{
NILS PETTER HELLSTRÖM
}

Department for History of Science and Ideas, Uppsala University, Box 629, 75126 Uppsala, Sweden (e-mail: petter.hellstrom@idehist.uu.se).

\begin{abstract}
To speak of evolutionary trees and of the Tree of Life has become routine in evolution studies, despite recurrent objections. Because it is not immediately obvious why a tree is suited to represent evolutionary history - woodland trees do not have their buds in the present and their trunks in the past, for a start - the reason why trees make sense to us is historically and culturally, not scientifically, predicated. To account for the Tree of Life, simultaneously genealogical and cosmological, we must explore the particular context in which Darwin declared the natural order to be analogous to a pedigree, and in which he communicated this vision by recourse to a tree. The name he gave his tree reveals part of the story, as before Darwin's appropriation of it, the Tree of Life grew in Paradise at the heart of God's creation.
\end{abstract}

KEY WORDS: evolutionary theory - tree imagery - science and culture - science and religion - science and society.

\section{INTRODUCTION}

In On the origin of species, Charles Darwin (1859: 129-130) evoked an arresting image of a tree struggling with itself. The image was vivid and violent, orderly and chaotic: twigs and branches killed each other for space and survival, but simultaneously yielded beauty and "the classification of all extinct and living species in groups subordinate to groups". Darwin's tree, in effect, was a family tree of all life, in which the buds were individuals and the branches their ancestral lineages. "As buds give rise by growth to fresh buds", Darwin wrote,

and these, if vigorous, branch out and overtop on all sides many a feebler branch, so by generation I believe it has been with the great Tree of Life, which fills with its dead and broken branches the crust of the earth, and covers the surface with its ever branching and beautiful ramifications.

This peculiar tree had matured in Darwin's mind for more than 20 years. In his notebooks on transmutation from the late 1830 s, written before he developed his theory of descent by natural selection, he had invoked the Tree of Life to visualize the interconnected history and classification of living beings. From this first appearance, there existed a curious, if unstated, relationship between text and diagram; three ramifying sketches of evolutionary development followed the first mentions of the "tree of life" in the 1837 notebook (Barrett et al. 1987: 177, 180), and a branching diagram appeared shortly before the Tree of Life passage in Origin (Darwin 1859: between 116 and 117).

Darwin, however, was not first to speak of the Tree of Life. Originally native to biblical Paradise, it was one of many trees that for centuries had been part of religious imagery. 
Its destiny since the appearance in Origin is fascinating: frequently employed in communication and teaching about evolution, and increasingly used as a marker of it (Hellström 2011), the Tree of Life now doubles as a "canonical icon" of evolution (Gould 1997).

Gould has not been alone in accusing the tree of reinforcing hierarchy and teleology (see, for example, Deleuze and Guattari 1980: 11-37). Another challenge, perhaps more disturbing, is posed by molecular studies of prokaryote evolution. Because these indicate extensive lateral gene transfer and genes within the same lineage with different evolutionary histories, an increasing number of scientists suggest that the construction of a universal Tree of Life is rendered impossible (see, for example, Doolittle 1999, 2000, 2009, 2010; Bapteste et al. 2009; O'Malley et al. 2010; Oren and Papke 2010). Even if at the heart of criticism lies the question of why the classification and history of life necessarily should be represented by a tree ${ }^{1}$, then this is not to say that the tree cannot serve this purpose. It is rather to say that the reasons why it does are historically and culturally, not scientifically, predicated.

So how did it happen that in 1859 a prominent British naturalist, who knew so much of real trees, included a metaphysical and metaphorical one in his groundbreaking work? And why did he name it the Tree of Life? To answer these questions, we must venture beyond natural history and inquire about Darwin's tree in relation to extra-scientific trees and to its scriptural precursor and namesake. ${ }^{2}$

\section{DARWIN'S TREE}

In 1837 , less than a year after his return from the Beagle voyage, Darwin recorded a curious stream of thought in the first of his transmutation notebooks. Here, for the first time, he invoked the "tree of life" to account for the historical development and present distribution of species. This, to my knowledge, is the first recorded use of the Tree of Life in the context of natural history.

Darwin posited a triple branching of his "tree of life" according to the elements of land, air and water, and a triple branching of each branch, as the descendant species either persisted or adapted to the other two elements. This family history explained why whales were not fish and bats not birds and why fish and penguins did not "pass into each other" (Barrett et al. 1987: 177), as they would have done in a Lamarckian evolutionary scheme, where life forms climbed the ladder of progress and every fish eventually became human. In Darwin's view, true affinity in nature was not functional but inherited. To sharpen his metaphor, Darwin considered abandoning the tree in favour of a coral, where "passages cannot be seen" (on the "coral of life", see Bredekamp 2005).

Already in 1837, it was clear what the Tree of Life meant to Darwin; the metaphor was genealogical, developmental, adaptational and taxonomic (Barrett et al. 1987: 176-177):

Would there not be a triple branching in the tree of life owing to three elements air, land \& water, \& the endeavour of each typical class to extend his domain into the other domains. \& subdivision three more, double arrangement. - if each Main stem of the tree is adapted for these three elements, there will be certainly points of affinity in each branch

A species as soon as once formed by separation or change in part of country. repugnance to intermarriage settles it

? We need not think that fish \& penguins really pass into each other. -

The tree of life should perhaps be called the coral of life, base of branches dead; so that passages cannot be seen. - this again offers contradiction to constant succession of germs in progress. - [inset: no only makes it excessively complicated.] 
[First sketch]

Is it thus fish can be traced right down to simple organization. -

birds - not.

[Second sketch]

Darwin sketched two dotted diagrams of ramifying, upward development. A third and similar sketch, not dotted but lined, appeared ten pages later, with a note on extinction scribbled almost onto it, but with no mention of the "tree of life" on the surrounding pages. None of these sketches illustrated evolution as such, but rather aspects of it. The first drawing illustrated adaptation to the three elements; the second, the long gaps in the fossil record; and the third, extinction (Gruber 1978: 126).

The ambiguous relationship between tree and diagram was repeated in Origin, whose stylized diagram was even less reminiscent of a natural tree than the notebook sketches. As far as records tell, Darwin did not refer to the notebook sketches or the Origin diagram as trees. Thus, although these communicated the same theme as the Tree of Life, it is dubious whether Darwin considered them to be trees. The common designation of them as such may in fact be a connection made by others to create coherence (on text and diagram, see Brink-Roby 2009; on Darwin and visual expression, see Voss 2009).

Text and diagram should not be confused, but also not fully separated. Instead they could be considered in their totality as a vehicle of thought: Gruber (1978: 135) argued that behind Darwin's thinking was "a group of images of wide scope" capable of "assimilating ... a wide range of perceptions, actions, ideas". As one of these, the Tree of Life served Darwin as an "image of nature deployed in evolutionary time" (Gruber 1978: 130). This is most poignant in Origin (Darwin 1859: 129):

\footnotetext{
The affinities of all the beings of the same class have sometimes been represented by a great tree. I believe this simile largely speaks the truth. The green and budding twigs may represent existing species; and those produced during each former year may represent the long succession of extinct species. At each period of growth all the growing twigs have tried to branch out on all sides, and to overtop and kill the surrounding twigs and branches, in the same manner as species and groups of species have tried to overmaster other species in the great battle for life. The limbs divided into great branches, and these into lesser and lesser branches, were themselves once, when the tree was small, budding twigs; and this connexion of the former and present buds by ramifying branches may well represent the classification of all extinct and living species in groups subordinate to groups.
}

Some of this came from Darwin's manuscript on natural selection, prepared between 1856 and 1858 (Stauffer 1975: 249-250). That the Tree of Life there consisted of "a few gigantic trees" adds to the uncertainty of whether Darwin had one or several trees in mind in Origin, where the relevant passage opened with a tree for "the beings of the same class" but ended with "the great Tree of Life", covering the face of the earth. This confusion may have been a legacy of the contemporary tendency of assigning one tree to each class or kingdom: Augier (1801) had drawn a tree for plants and Hitchcock (1840) one for plants and one for animals. Before Origin, Darwin's tree had also appeared in a letter to Asa Gray in $1857^{3}$ and in the paper read before the Linnean Society in 1858 (Darwin 1858: 53), although in those two instances the analogy was with an unnamed tree.

Although the Tree of Life appeared in Darwin's writings both in the 1830s and the 1850s, and although later trees resembled earlier ones by virtue of name and function, it is hard to account for the two decades of silence in between, during which Darwin prepared drafts of his evolutionary theory without any reference to the Tree of Life. We can only speculate about the role it played for his thinking during these intervening years. 


\section{THE TAXONOMICAL TREE}

Before the end of the eighteenth century, it was not obvious that a tree was best suited to represent the order of nature. Carl Linnaeus, for example, did not invoke any tree image in his published writings, even as his fractional and hierarchical taxonomy was in harmony with the Origin diagram: the regna branched into classes, then into ordines, then into genera, and finally into species (Linnaeus 1735). But in other branches of the sciences, the tree was already the organizing principle; when Darwin appropriated the Tree of Life to visualize evolutionary classification, its biblical twin, the Tree of Knowledge, had already been used for centuries to visualize the hierarchy of learning. A passage from the account of the 1831-1836 Beagle voyage by the ship's commander, Robert FitzRoy (1839: 658), illustrates the fluidity between science and religion during Darwin's time:

For geology, as a useful branch of science, I have as high a respect as for any other young branch of the tree of knowledge, which has yet to undergo the trial of experience; and no doubt exists in my own breast that every such additional branch, if proved by time to be sound and healthy, will contribute its share of nourishment and vigour to the tree which sprung from an immortal root.

In England, this metaphor was well-established. Francis Bacon had compared the "partitions of knowledge" to the "branches of a tree that meet in a stem" (Spedding et al. 1857: 346). Bacon did not apply the phrase Tree of Knowledge to his allegory, but he clearly related the two, remarking that "the knowledge that now is, is but a shrub, and not that tree which is never dangerous, but where it is to the purpose of knowing Good and Evil" (Spedding et al. 1857: 227). The allegory was poignantly genealogical, as in Novum organum, in 1620, he declared natural philosophy "the great mother of the sciences" (Spedding et al. 1858: 78-79). In Advancement of learning, Bacon wrote (Spedding et al. 1857: 353):

I intend Philosophia Prima, Summary Philosophy, and Metaphysic, which heretofore have been confounded as one, to be two distinct things. For the one I have made as a parent or common ancestor to all knowledge, and the other I have now brought in as a branch or descendant of Natural Science.

Following Bacon, Descartes (1647) and the Encyclopaedists used tree analogies to systematize knowledge; Diderot even described the encyclopaedic vision in its entirety as a "genealogical tree" (Klapisch-Zuber 2007: 307; Ariew 1992: 101-104); his vision was rendered graphical by Chrétien Roth in 1769 (Mouchon 1780) (Figure 1). Yet the roots of such "genealogical" trees of knowledge were even older. In 1295 the Mallorcan theologian Raymond Lull had described a taxonomic Tree of Knowledge in his Arbor scientiae. Lull's appropriation was not as direct as may appear in translation, the Latin name for the biblical Tree of Knowledge was lignum scientiae rather than arbor scientiae, but half of Lull's roots were divine and the name itself a close enough pun to effect the association. By virtue of Lull's reputation and the beauty of the trees that illustrated printed editions of his book, Arbor scientiae proved one of the more significant instances of cross-fertilization between the biblical trees, ligna, and diagrammatical arbores.

An arbor was a hierarchical table of the classical tradition, typically a descending schema of circles joined by lines. It organized a hierarchical and fractional universe, structured by successive subdivisions. During the Middle Ages, cross-fertilization between the biblical ligna and the diagrammatical arbor - instituted by Lull and others - made the previously sterile arbor increasingly tree-like and the distinction between arbor and ligna increasingly porous: in English as in other languages, the biblical name began to be applied 


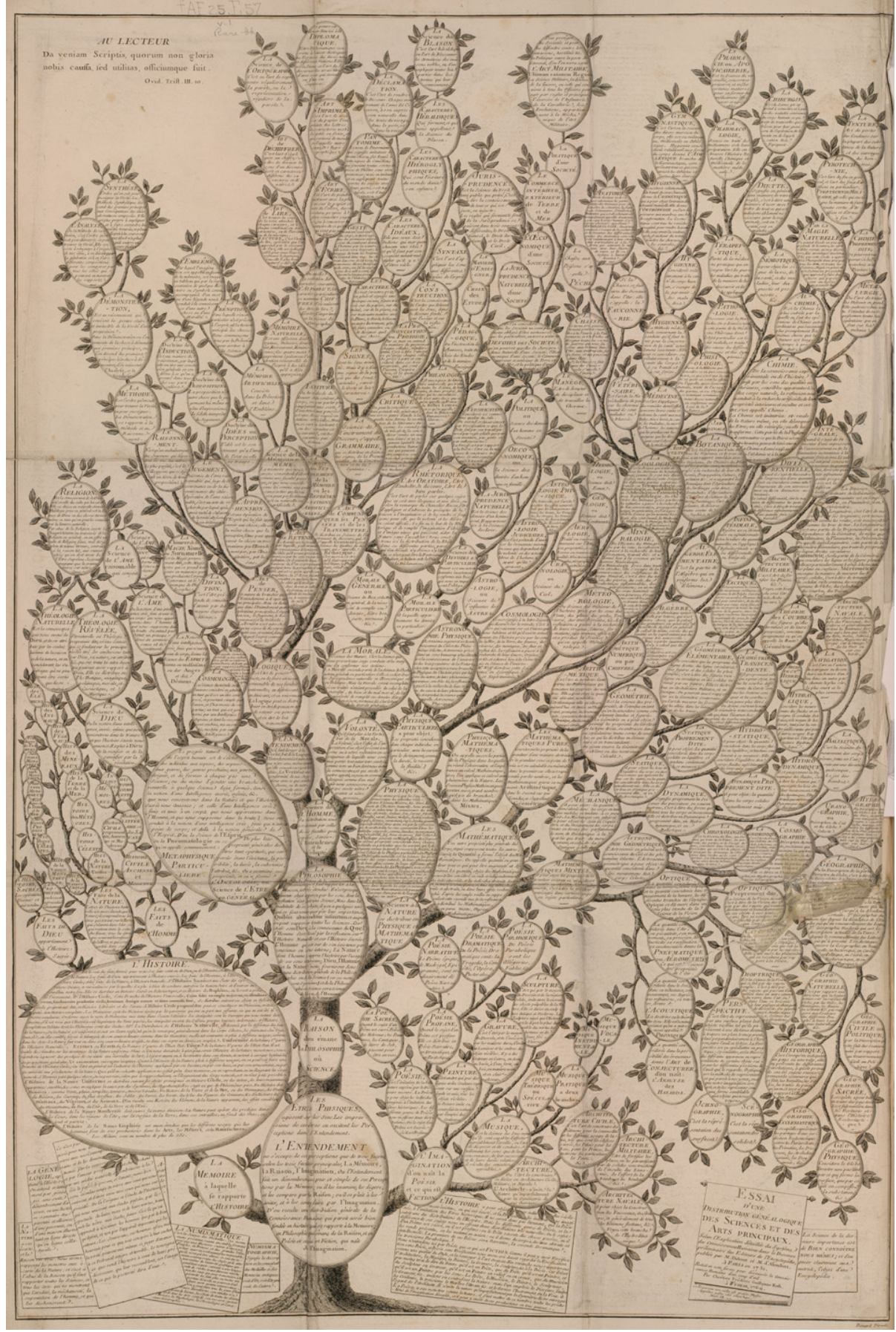

Figure 1. Chrétien Roth's diagram entitled "Essai d'une distribution généalogique des sciences et des arts principaux", produced in Weimar in 1769, which illustrated Diderot's vision of a "genealogical tree" of all the sciences and arts (from Mouchon 1780). (Reproduced by permission of the ARTFL Encyclopédie Project, University of Chicago.) 
to arbores, such as those of Lull and Bacon. As there is no possibility that Darwin was not aware of both uses of the term, the extended meaning of the Tree of Knowledge may have suggested to him the conception of its biblical twin as the evolutionary Tree of Life.

The intellectual world of the Middle Ages was a virtual forest of arbores. There were classificatory "trees" for almost everything, from virtues and vices to elements and sacred genealogy (Klapisch-Zuber 2000). Yet, the arbor that most directly would influence natural history was the arbor porphyriana. This "tree", designed to illustrate Aristotelian logic, presented nature as an interconnected system, with species united into genera and organized into a hierarchy, each station more advanced than the previous. In natural history, the Tree of Porphyry helped blend branching taxonomy with the hierarchical scala naturae (Hacking 2007: 225).

Perhaps it was only a question of maturation when, by the second half of the eighteenth century, the tree emerged as an organizing principle in natural history. As previously with other arbores, discursive images preceded graphical ones. "Does the scale of nature branch out as it advances?", asked Bonnet (1764: 59, 1766: 50): "May insects and shell-fish be two lateral and parallel branches of this great stem? May the frog and the lizard, which bear so near a resemblance to insects, be a ramification of them? Are the lobster and crab in like manner a branch of shell-fish?" Buffon (1766: 335) used similar terminology, whilst Pallas (1766: 23-24; Archibald 2009: 563) pushed the analogy further, to a tree that was strikingly similar to Darwin's Tree of Life, although static:

... the system of organic bodies is best of all represented by an image of a tree which immediately from the root would lead forth out of the most simple plants and animals a double, variously contiguous animal and vegetable trunk; the first of which would proceed from mollusks to fishes, with a large side branch of insects sent out between these, hence to amphibians and at the farthest tip it would sustain the quadrupeds, but below the quadrupeds it would put forth birds as an equally large side branch.

The first naturalist to produce a diagram that actually looked like a tree was probably Augustin Augier, whose "Arbre botanique" appeared in 1801. Augier searched for a classification scheme that would emulate the "true natural order" of Creation. After he had failed to arrange all plants into one gradual series, he contended that this was due to the proper arrangement being tree-like, with many series united at the base (Augier 1801: i-viii; Stevens 1983: 204-206). Augier's hierarchical tree (Figure 2) obeyed the logic of scala naturae and arbor porphyriana, with mosses and fungi at the bottom and the "most perfect" plants at the summit (Stevens 1983: 209). Although it was not chronological it was expressly genealogical (Augier 1801: 2; Stevens 1983: 206):

\footnotetext{
A figure like a genealogical tree appears to be the most proper to grasp the order and gradation of the series or branches which form classes or families. This figure, which I call a botanical tree, shows the agreements which the different series of plants maintain amongst each other, although detaching themselves from the trunk; just as a genealogical tree shows the order in which different branches of the same family came from the stem to which they owe their origin.
}

Given Augier's obscurity (Stevens 1983: 203), it cannot be assumed that Darwin knew of his "botanical tree". Still, its existence demonstrates that it was possible in 1801 to visualize nature by analogy to a genealogical tree - even when the tree was not properly genealogical.

The static world, however, was increasingly in question. In the year of Darwin's birth, Lamarck (1809: 463) published an evolutionary diagram that has been declared the first evolutionary tree (Voss 1952: 17; Archibald 2009: 565). The diagram, however, was not named tree but "tableau" by its author. In so far as it consisted of dotted, bifurcating, 


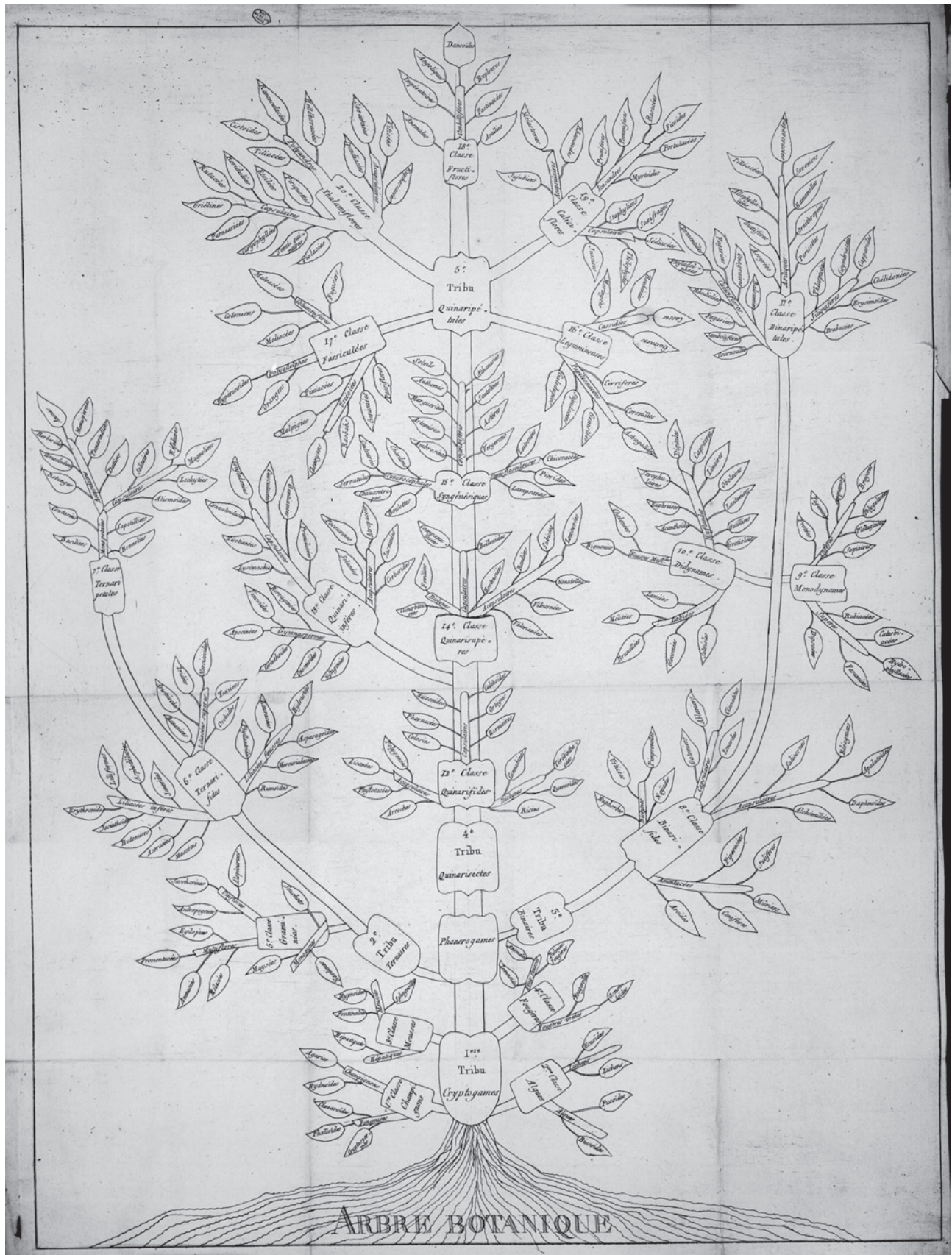

Figure 2. Augustin Augier's "Arbre botanique" representing the "genealogical" classification of plants from Essai d'une nouvelle classification des vegetaux (1801). (Reproduced by permission of the Bibliothèque centrale du Muséum national d'Histoire naturelle, Paris.) 
descending lines, it more resembled the arbor porphyriana or a descending scala naturae. Even so, Lamarck (1809: 462; Voss 1952: 17) employed the received arboreal vocabulary of classification:

The following table will facilitate the understanding of what I have just set forth. One will see there that, in my opinion, the animal scale begins by at least two distinct branches, and that, in the course of its extension, several branches appear to terminate it in certain places.

From this cursory inventory of trees in natural history before 1837, when Darwin first recorded his Tree of Life, three things are clear. First, arboreal and genealogical analogies were common in taxonomy. Secondly, no one before Darwin had proposed genealogy proper as the organizing principle of nature. Thirdly, no one had applied the phrase Tree of Life to a taxonomic tree. ${ }^{4}$ Thus, although existing trees and tree-language probably contributed to and reinforced Darwin's inclination, it is unsatisfactory to search for the roots of the Tree of Life only within natural history.

\section{THE GENEALOGICAL TREE}

In nineteenth-century Britain, trees were routinely used to visualize genealogical relations. ${ }^{5}$ Like taxonomic trees, genealogical trees had developed from the tradition of the arbor, and more specifically from the arbor iuris and arbor consanguinitatis, both used to regulate succession and to define inbreeding, and whose graphical representation - descending schemes of names inserted into compartments - recalled trees (Watson 1934: 41-42; Klapisch-Zuber 2007: 294). Because genealogical arbores were widely circulated and enjoyed church support (Watson 1934: 42), their descending character may have contributed to reinforce and naturalize the discursive image of "descent", as employed by Darwin in The descent of man (1871).

During the Middle Ages, genealogical arbores underwent the same naturalization as other arbores; the name thus colonizing the visual expression (Klapisch-Zuber 2007: 294295). Instrumental in this development was the Tree of Jesse, the visual representation of Jesus' kingly genealogy as inspired by messianic prophecy. Because the prophet described the Messiah as a flower rising from the root of Jesse, King David's father (Isaiah 11: 1-2), the typical representation was an ascending vegetal structure connecting ancestral kings to Christ at the summit. At the apex of its popularity, in the twelfth century, the Tree of Jesse was an established theme in book illuminations and church decoration (Johnson 1961: 1; Bouquet 1996: 50; Klapisch-Zuber 2007: 295).

Because the genealogical tree came from a union of the descending, ramifying and stylized arbor with the ascending, linear and vegetal Tree of Jesse, it is not surprising that many of its striking, early manifestations appeared in the religious context. One seminal appearance was in John Speed's biblical genealogies (1611), prominently bound together with the first edition of the King James Bible and still in print during Darwin's lifetime (for example, Speed 1817). Speed adhered for the most part to the conventions of the genealogical arbor, with descending diagrams of circled names connected by lines. Yet Noah's genealogy was a striking exception: a naturalized tree, growing out of the ark (Figure 3). That the genealogical tree from the very beginning was applied to sacred genealogy, in a religious society, probably contributed to its longstanding impact. 


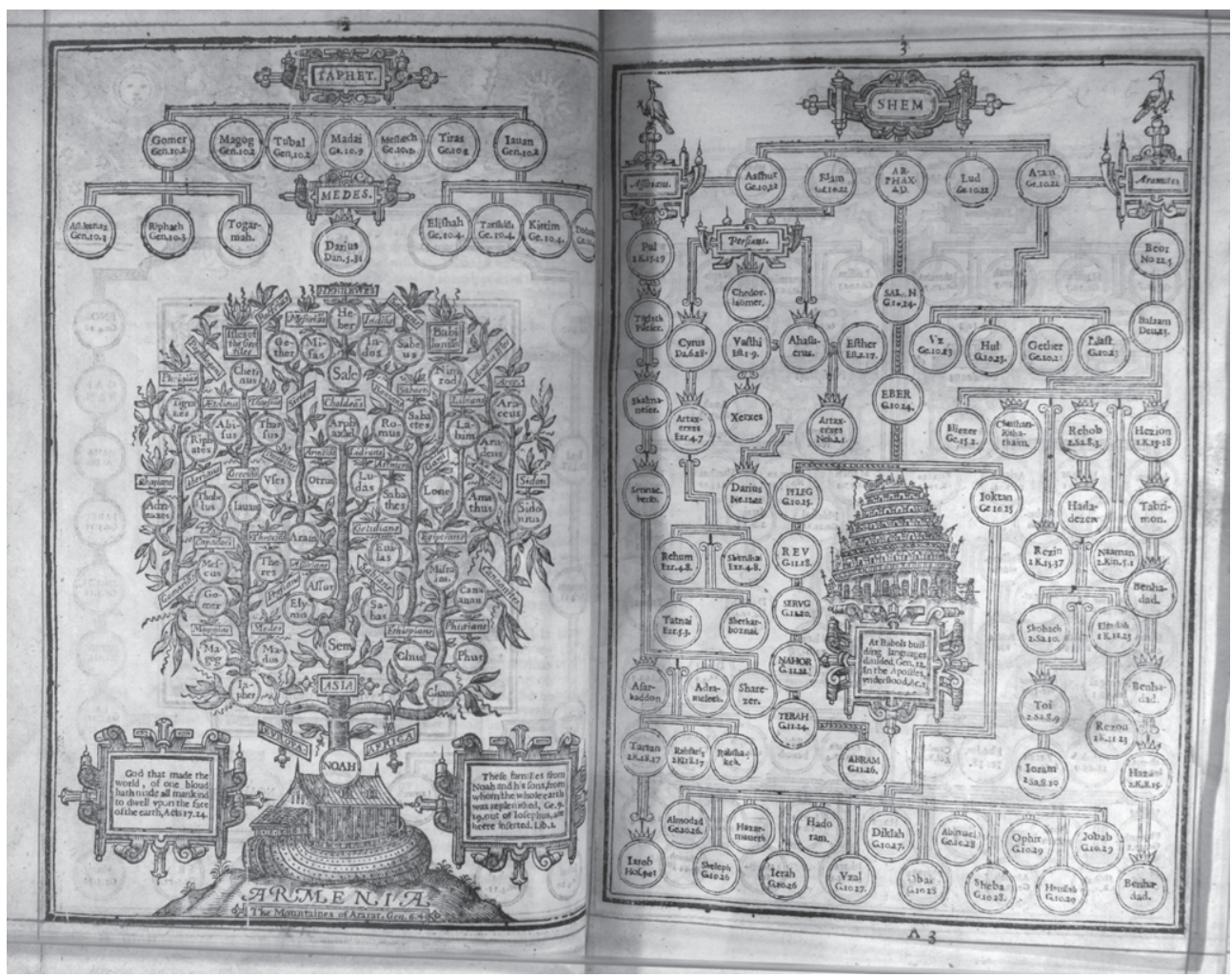

Figure 3. Noah's family tree (left) from John Speed's The genealogies recorded in the Sacred Scriptures (1611). (Reproduced by permission of Växjö stadsbibliotek, Sweden.)

By the nineteenth century, the practice of drawing genealogical trees was well established, especially with the privileged classes. The past had also more generally become the prerequisite for understanding the present. The concept of evolution was not limited to natural history but part of "an awakened sense of historicity", an "interest in the origin of things and a view of history, not as a haphazard flow of disjointed events, but as development" (von Wright 1993: 215). Not only were geologists such as Lyell opening up unprecedented expanses of time; theories of the development of society, such as those of Hegel, Comte, Spencer, Marx and Nietzsche, were simultaneously on the rise. After William Jones addressed the Asiatick society of Calcutta in 1786 and explained linguistic affinities between Europe and India by shared origins, genealogical reconstructions based on linguistic affinities gave rise to genealogical trees of languages, the first of which was probably Félix Gallet's "Arbre généalogique des langues mortes et vivantes", dated to around 1800 (Auroux 1990: 228).

Towards the end of the eighteenth century, genealogy also began to infiltrate natural history. In an early instance, Buffon (1766: 335; see Voss 1952: 17) linked species in lineages, employing the received arboreal terminology:

... the elephant, the rhinoceros, the hippopotamus, the giraffe form simple genera or species which are propagated only in a direct line and have no collateral branches; all the others [land animals] appear to form families in which one ordinarily notices a principal and common trunk, from which seem to have issued different stems and the more numerous, as the individuals of each species are smaller and more prolific. 
In Germany, Kant followed Buffon, and Goethe followed Kant (Sloan 2006). And then, in 1809, Lamarck proposed a theory of evolution reminiscent of the evolutionary ideas expressed in 1794 by Darwin's grandfather Erasmus Darwin in Zoonomia. But even as time and development became increasingly important, the problem that Darwin addressed in the 1830s was the same as had engaged Linnaeus a century earlier: the natural system of classification. After Linnaeus had died in 1778, the discovery of the natural order of Creation remained the main trophy of natural history and continued to motivate naturalists. In 1838, Darwin thought he had found it: "We now know what is the natural arrangement", he declared in his "C" notebook, "it is the classification of relationship, latter word meaning descent" (Barrett et al. 1987: 286). In the 1842 and 1844 manuscripts, when he first set out to formulate his theory, Darwin made himself even clearer: "The proper arrangement of species into groups, according to the natural system, is the object of all naturalists, but scarcely two naturalists will give the same answer to the question" (Darwin 1909: 199); “... If used in simple earnestness the natural system ought to be a genealogical" (Darwin 1909: 36); “... we see that all the leading facts in the affinities and classification of organic beings can be explained on the theory of the natural system being simply a genealogical one" (Darwin 1909: 212).

In Origin, Darwin (1859: 420, 422) wrote:

All the ... difficulties in classification are explained ... on the view that the natural system is founded on descent with modification; that the characters which naturalists consider as showing true affinity between any two or more species, are those which have been inherited from a common parent, and, in so far, all true classification is genealogical; that community of descent is the hidden bond which naturalists have been unconsciously seeking ... The reader will best understand what is meant, if he will take the trouble of referring to the diagram in the fourth chapter. ... the natural system is genealogical in its arrangement, like a pedigree.

Darwin's theory proposed to solve Linnaeus's problem by recourse to genealogy. The suitable model for genealogy was the tree. Earlier "genealogical trees" in taxonomy and natural history, together with the established habit of describing relations in nature in arboreal, genealogical terms, most probably contributed, but, importantly, no earlier taxonomy had been properly genealogical, showing common descent. Whereas genealogy had been an allegory to earlier naturalists, Darwin understood the allegory literally; his contribution, in a sense, was therefore to think the metaphor to its end. But why was he first to do so? Or, to speak with Hacking (2007: 221): "Why did we have to wait until Darwin before it became obvious that the classification of living things should be presented as a tree?"

The answer could perhaps be approximated through Darwin's family history. The Darwins and Wedgwoods were wealthy and well known, conscious and proud of their history and importance. Darwin's sense of stemming from an "ancient" and "august" family is manifest in an 1839 letter to his second cousin William Darwin Fox. In the letter Darwin also expressed a particular sense of inherited rights to the vocation of naturalist. He may have been joking, but it was no isolated expression: two years earlier, Darwin had written "Zoonomia" at the head of his first transmutation notebook (Barrett et al. 1987: 170), the title of his grandfather's great treatise:

Talking of family affairs, can you tell me from memory what the motto to our crest is for I mean to have a seal solemnly engraved ... it was aude ? et - ?... When at Shrewsbury I had a regular hunt through some old papers \& pedigrees relating to our most ancient family, which as you say is older than the heralds office ... The pedigrees want filling up terribly; so ancient a family ought not to be neglected ... By the way Hensleigh Wedgwood made a curious discovery regarding our august family, which I must tell you, that a W. Darwin my 
great grandfather is described in the Phil. Transacts for 1719, as a person of curiosity, who discovered the remains of a giant, evidently an Icthyosaurus. - so that we have a right of hereditary descent to be naturalists \& especially geologists. ${ }^{6}$

It is well known how Darwin's naturalist grandfather inspired him on the unity and evolution of organic life, having proposed that life originated from one or two "filaments", differences of type resulting from subsequent change (Darwin 1794:500). Less well known is the way Darwin adopted his grandfather's peculiar view of trees, as compounds of individuals rather than as contained organisms (Darwin 1794: 102):

The individuals of the vegetable world may be considered as inferior or less perfect animal; a tree is a congeries of many living buds, and in this respect resembles the branches of coralline, which are a congeries of a multitude of animals. Each of these buds of a tree has its proper leaves or petals for lungs, produces its viviparous or its oviparous offspring in buds or seeds; has its own roots, which extending down the stem of the tree are interwoven with the roots of the other buds.

Clearly influenced by his grandfather, Darwin noted in 1838 that "my pleasure in Kensington Gardens has often been greatly excited by looking at trees as great compound animals united by wonderful \& mysterious manner" (Barrett et al. 1987: 529), and in 1844 he declared that "It is very doubtful whether the flowers and leaf-buds, annually produced from the same bulb, root, or tree, can properly be considered as parts of the same individual" (Darwin 1909: 58). ${ }^{7}$ Darwin's understanding of trees may have reinforced his idea of a genealogical tree, even as the organization of real trees may have appeared to coincide with that of the metaphysical.

Darwin's interest in animal breeding and domestication may also have reinforced his preoccupation with pedigrees and genealogy. This interest was not limited to the naturalist period of his life or to pigeons (see Secord 1981). As a child, Darwin grew up in agricultural Shropshire, and from an early age, he loved hunting; a sport where not only the hunting gentlemen but also their horses and dogs had pedigrees. After Darwin had been offered a place on board the Beagle in 1831, it was as a young country gentleman he wrote to his mentor Henslow that "till one to day I was building castles in the air about hunting Foxes in Shropshire, now Lamas in S America". 8 A passage from Origin would sum up Darwin's upper-class world, where the place of an individual was dictated by blood, and where greyhounds and racehorses came to mind when discussing functionally similar but biologically unrelated animals (Darwin 1859: 427):

The resemblance of the greyhound and race-horse is hardly more fanciful than the analogies which have been drawn by some authors between very distinct animals ... For animals, belonging to two most distinct lines of descent, may readily become adapted to similar conditions, and thus assume a close external resemblance; but such resemblances will not reveal - will rather tend to conceal their blood-relationship to their proper lines of descent.

Darwin (1859: 431) himself related his proposed natural system to the family trees of the privileged classes, comparing the difficulty of establishing relations in nature to the difficulty "to show the blood-relationship between the numerous kindred of any ancient and noble family, even by the aid of a genealogical tree".

But the tree was threatening to undermine the aristocratic world view even as it came from it. When Darwin wrote of "a single progenitor" (Darwin 1859: 413) or the "one primordial form" (Darwin 1859: 484), his theory seemed to threaten not only the select character of the wealthy and the white, but also of humanity. "Our ancestor", wrote Darwin in a letter to Lyell, in 1860, "was an animal which breathed water, had a swim-bladder, a great swimming tail, an imperfect skull, and undoubtedly was an hermaphrodite! 
Here is a pleasant genealogy for mankind." When Darwin invited animals into the human family, he both fed on and rivalled the Christian doctrine of common origins in Adam. The tree, favoured for human genealogy by Speed and others, remained the model.

Desmond and Moore (2009) have demonstrated that Darwin's opposition to slavery motivated him to prove that apologists of slavery were wrong to make the human races separate species. In his notebooks, Darwin distinguished the ways in which beliefs about separate racial creation were consonant with interests in slavery, by comparing the treatment of slaves to that of animals: "Animals - whom we have made our slaves we do not like to consider our equals", he noted in 1838, "Do not slave holders wish to make the black man other kind?" (Barrett et al. 1987: 228). But Darwin went further than other abolitionists, to oppose also the doctrine of separate human creation: "Man in his arrogance thinks himself a great work. worthy the imposition of a deity", he wrote in 1838, "more humble \& I believe true to consider him created from animals" (Barrett et al. 1987: 300). Thus, from early on, moral values related intimately to his theory of common descent. This is manifest in the following note, also from 1838 (Barrett et al. 1987: 286):

\footnotetext{
Animals have voice, so has man ... Man has expression. - animals signals. (rabbit stamping ground) Man signals.- animals understand the language, they know the crys of pain, as well as we.-

It is our arrogance, to raise on the same shelf- to (look at common ancestor, (scarcely) conceivable in savages) Has not the white Man, who has debased his Nature by making slave of his fellow black, often wished to consider him as other animal - it is the way of mankind. \& I believe those who soar above Such prejudices, yet have justly exalted nature of man. like to think his origin godlike, at least every nation has. done so as. yet.We now know what is the natural arrangement, it is the classification of relationship; latter word meaning descent.
}

"How extremely stupid not to have thought of that!" Huxley (1887: 197) reported to have thought on reading Origin. Indeed, that species were products of history, through ancient lineages, might have been obvious in England in 1859. By then, enough factors were aligned for a genealogical tree to emerge as the self-evident solution to the taxonomical problem. Genealogy had closed in on Darwin on all sides, from the so-called "genealogical trees" and the genealogical terminology omnipresent in the many branches of learning, including natural history, to the properly genealogical trees of sacred and profane family history and of animal breeding.

When trying to understand how Darwin's theory was later appropriated to justify social stratification, violent domination, and mass-murder, it should be remembered that the Tree of Life always had its better and worse members; this is clear from the frequency of the adjectives "high" and "low" in all of Darwin's writings. Instead of side-passing the historical context that helped shape the Tree of Life, it would be more useful to discuss the inherent ambiguities in Darwin, who was not only a naturalist, but also a man of his time and class. And how could his genealogical tree have escaped a history of at least a millennium, during which it had been used to maintain hierarchies and to naturalize social injustice, and even to prove how Jesus was God by virtue of his royal blood?

\section{THE COSMOLOGICAL TREE}

As a symbol of cosmic unity and of the regeneration of life, the tree is ancient. Life-giving trees in the midst of mythological gardens are mentioned on Mesopotamian cuneiform 
tablets (James 1966: 68-70, 1968: 241-242), and the concept may well precede writing. The phrase Tree of Life came to English with the translation of the Bible, where it appeared in prominent first and last place positions. In the primordial Paradise described in Genesis, Adam and Eve ate from the Tree of Knowledge and thus lost the Tree of Life (Genesis 2: 9; 3: 22-24). In the future Paradise envisioned in Revelations, the Tree of Life will again stand at the centre of existence (Revelations $2: 7 ; 22: 2$ ). The Tree of Life also figures in the Bible as an allegorical image of regeneration, vitality and prosperity (Proverbs 3: 18; 11: 30; 13: 12; 15: 4; II Esdras 2: 12; 8: 52). In this derived sense, the Tree of Life remained important to Christian discourse well into Darwin's time, as is clear from its recurrence in the titles of spiritual publications throughout the nineteenth century. ${ }^{10}$

During the Middle Ages, another layer of meaning was added to the Tree of Life, as theologians proclaimed the symmetry between the first Adam, who brought death into the world, and the second, who redeemed humanity on a cross crafted from Edenic wood. Through such teleologies, Christ became the Tree of Life incarnated, a promise of regeneration and deliverance from death (Schama 2004: 219-220; James 1968: 244-245).

In its biblical sense, the Tree of Life was still a common metaphor in Darwin's time, both in religious and artistic imagery. Often it appeared in opposition to the Tree of Knowledge. In the early nineteenth century Byron (1817: 7) declared that "The Tree of Knowledge is not that of Life", while Goethe (1808: 124; 1833: 70) wrote that "Grey, my dear friend, is all theory, and green the golden tree of life". Darwin must have come across such references, yet his relationship to the trees of God was more intimate than that: he had brought them with him onboard the Beagle.

Beer (2009: 27) has argued that Darwin's early reading influenced his imaginative development. In particular, she has drawn attention to "The intimacy and solitariness of his contact with Milton" (Beer 1985: 549; 2009: 27). In his autobiography, Darwin himself recalled that: "Up to the age of thirty, or beyond it, poetry of many kinds, such as the works of Milton, Gray, Byron, Wordsworth, Cole-ridge, \& Shelley, gave me great pleasure" (Darwin 1887: 1: 100). "Milton's Paradise Lost had been my chief favourite, \& in my excursions during the voyage of the Beagle, when I could take only a single small volume, I always chose Milton" (Darwin 1887: 1: 69). Darwin literally carried Milton's retelling of Genesis around the world.

In Paradise lost the tree theme was even more emphatic than in the Biblical original: the Tree of Knowledge appeared in the second line and the poet repeatedly returned also to the Tree of Life, "the middle Tree and highest" (Milton 1674: 4: 193). ${ }^{11}$ Throughout the poem, Milton sustained a tension between Life and Knowledge, as in the following passage (Milton 1674: 4: 214-219):

\footnotetext{
Out of the fertil ground he caus'd to grow

All Trees of noblest kind for sight, smell, taste;

And all amid them stood the Tree of Life,

High eminent, blooming Ambrosial Fruit

Of vegetable Gold; and next to Life

Our Death the Tree of Knowledge grew fast by.
}

It is clear from records that Paradise lost remained in Darwin's mind throughout his voyage and life. In an 1832 notebook entry from Chile, Darwin compared the ocean to the infernal regions of chaos (Keynes 1988: 111), in a letter to Henslow in the same year 
he described a toad with reference to Milton's Satan ${ }^{12}$, and in a note from 1835 he reminded himself to bring along Milton's book (Chancellor and van Wyhe 2009: 480). In The expression of the emotions in man and animal, Darwin (1872: 304-305) still referred to Milton. Even as he sat down to write his autobiography, Paradise lost came to his mind, now as the privileged reference for Creation, even before the Bible (Darwin 1887: 2: 187):

I find no difficulty in imagining that, at some former period, this universe was not in existence; and that it made its appearance in six days (or instantaneously, if that is preferred), in consequence of the volition of some preexistent Being ... I had not then, and I have not now, the smallest a priori objection to raise to the account of the creation of animals and plants given in 'Paradise Lost,' in which Milton so vividly embodies the natural sense of Genesis.

In the nineteenth century, scientific works drew on literature, and vice versa, so that "metaphors, myths and narrative patterns could move rapidly and freely to and fro between scientists and non-scientists" (Beer 2009: 5). Darwin's Cambridge patron Adam Sedgwick, for example, used to quote Milton at length (Barrett 1974: 149), and Lyell referred to Paradise lost in Principles of geology (Lyell 1830: 37, 431; 1832: 135; 1833: 89). Onboard HMS Beagle, Darwin read Lyell's geology along with Milton's poetry (Burkhardt and Smith 1985: 562-563).

Milton's vivid account of Creation, with the centrality it accorded to the Tree of Life, impressed the young Darwin, who read descriptions of Paradise in paradisiacal places: "Epithet after epithet was found too weak to convey to those who have not visited the intertropical regions, the sensation of delight which the mind experiences", Darwin (1839: 591) concluded. He described trees as others describe humans: they were "noble" and "remarkable", "beautiful" and "handsome", sometimes "curious" and "ugly", "fine" or "stately" (Darwin 1839: 10, 24, 28, 36, 80, 312, 316). "In my last walk", Darwin (1839: 591) wrote, "I stopped again and again to gaze on these beauties, and endeavoured to fix for ever in my mind an impression, which at the time I knew, sooner or later must fail."

Darwin travelled on the Beagle from 1831 to 1836. Upon returning to England, in 1837, there appeared the first record of the Tree of Life in his notes. That Darwin knew well whence he took the name for his tree is beyond doubt. Still, there may have been other influences that helped shape it.

In March 1841, Darwin read a newly published book, Heroes, hero-worship, and the heroic in history, by Thomas Carlyle, a family acquaintance. ${ }^{13}$ Carlyle's book included a striking description of the "old Norse view of Nature", imagined as the cosmic ash-tree Yggdrasil. Darwin had only known Carlyle personally since 1838, so the poet cannot have influenced him in 1837. Yet, Carlyle's Yggdrasil may have influenced the Tree of Life as it was presented in Origin. Notice how Carlyle's Tree of Existence gathers "All Life", the boughs being nations and "every leaf of it a biography"; notice also how it is described as a "view of Nature", and how, as later in Darwin, the tree is "beautiful and great" (Carlyle 1841: 32-33):

I like, too, that representation they have of the Tree Igdrasil. All Life is figured by them as a Tree. Igdrasil, the Ash-tree of Existence, has its roots deep down in the kingdoms of Hela or Death; its trunk reaches up heavenhigh, spreads its boughs over the whole Universe: it is the Tree of Existence. At the foot of it, in the Deathkingdom, sit Three Nornas, Fates, - the Past, Present, Future; watering its roots from the Sacred Well. Its 'boughs,' with their buddings and disleafings, - events, things suffered, things done, catastrophes, - stretch through all lands and times. Is not every leaf of it a biography, every fibre there an act or word? Its boughs are 
Histories of Nations ... It is Igdrasil, the Tree of Existence. It is the past, the present, and the future; what was done, what is doing, what will be done; 'the infinite conjugation of the verb To do.' ... I find no similitude so true as this of a Tree. Beautiful; altogether beautiful and great. The 'Machine of the Universe,' - alas, do but think of that in contrast! ... Well, it is strange enough this old Norse view of Nature.

Carlyle wrote: "I find no similitude so true as this of a Tree." "I believe this simile largely speaks the truth", echoed Darwin. The affinities, given that Darwin read Carlyle, are striking. Thus, although Darwin recorded his Tree of Life already in 1837, and although Darwin was critical of Carlyle (Desmond and Moore 2009: 131-134, 142) ${ }^{14}$, the Tree of Existence may have reinforced Darwin's tree and contributed to shape it in its final form.

Just as the image of the entangled bank concluded Origin, so the image of the tree concluded the chapter on natural selection. But whereas the entangled bank only made the present visible, the Tree of Life invoked the invisible. The tree had always been there; like Yggdrasil it was past, present, and future, and therefore fit to accommodate teleology in a way that the entangled bank could not: "let us recognize Darwin's great service to natural science in bringing back to it Teleology", wrote the ever pious Gray (1874: 479) in American naturalist. "What you say about teleology pleases me especially", Darwin (1887: 3: 189) replied. "I have always said you were the man to hit the nail on the head." The tree, employed since the Middle Ages to vizualize a teleological understanding of history, has also served such tendencies in evolutionism. In a striking example, the BBC television production Charles Darwin and the Tree of Life, from 2009, the mammals, subdued by roaring reptiles, finally prevail with the dawn of a new era; they are visually carried toward heaven by the Tree of Life itself.

Bouquet (1995: 43-44) has argued that the "aesthetic continuity" between biblical and evolutionary history helped render evolution "irrefutable". This "representational constancy" meant that "although evolutionary theory contested the literal interpretation of the biblical Creation story, it borrowed the very same genealogical motif". That Darwin named his genealogical tree after the biblical symbol of regeneration of life - and thus made reference to it - also effected a continuity in redemptive traits: "Our death is not an end if we did live on in our children and the younger generation", wrote Albert Einstein in 1926. "For they are us, our bodies are only wilted leaves on the tree of life". ${ }^{15}$ To Einstein, Darwin's Tree of Life, like its biblical precursor, promised deliverance from death. Such fluidity between science and religion may provoke some, but there is no reason to think that it was disturbing to Darwin, who was neither literalist nor atheist.

Perhaps it could even be said that Darwin's theory, responding to an ancient human search for origins, required a tree at its centre. The tree, "shedding its verdure in the autumn to bring forth its shoots and buds in the spring", early on became "the perfect symbol" of the cyclical mystery of life (James 1968: 249); it gathered "the basic themes of creation, redemption and resurrection" and served as "an ultimate source of ever-renewing life at the centre of the cosmos" (James 1966: 1). Just as the Tree of Life had stood at the heart of Creation, so it took the corresponding position in a new universe not unlike the Christian: awe-inspiring, beautiful, orderly, harmonious, and meaningful. This universe was not Goethe's "grey theory", facts and order without appeal, the Tree of Knowledge in opposition to the Tree of Life. It was an aesthetic, lyrical and appealing vision; it proposed a new genesis and new laws - and a new Tree of Life planted in the midst of a new, more tangled garden. 


\section{ACKNOWLEDGMENTS}

I thank James Moore, Gillian Beer, Anne Secord, James Secord, Eleanor Robson, Jesse Olszynko-Gryn, Jenny Bangham, Adrian Desmond, Christiane Klapisch-Zuber, David Feller, Doina-Cristina Rusu, Maggie Barker, Sophie Jouffreau, and an anonymous referee.

\section{NOTES}

${ }^{1}$ Darwin also considered the "coral of life" (Barrett et al. 1987: 177) and spoke of a "web of affinities" (Darwin 1859: 434).

${ }^{2}$ Beer (2009: 32-33, 86) is acknowledged for mentioning the biblical tree.

${ }^{3}$ C. Darwin to A. Gray, 5 September 1857 (Burkhardt and Smith 1990: 449).

${ }^{4}$ For the history of trees in natural history, see Voss (1952) and Ragan (2009).

${ }^{5}$ The Oxford English dictionary reports the use of arboreal language for genealogy since the Middle Ages.

${ }^{6}$ C. Darwin to W. Darwin Fox, 24 October 1839 (Burkhardt and Smith 1986: 234-235).

${ }^{7}$ Darwin (1839: 261-262) also repeated his grandfather's comparison between coralline and trees.

${ }^{8}$ C. Darwin to J. S. Henslow, 5 September 1831 (Burkhardt and Smith 1985: 142).

${ }^{9}$ C. Darwin to C. Lyell, 10 January 1860 (Burkhardt et al. 1993: 29).

${ }^{10}$ See for example Kennedy (1854), Cumming (1857), Smith (1860) and Shepheard (1864).

${ }^{11}$ It is not established which edition Darwin carried; hence all references to the first complete edition of 1674 .

12 C. Darwin to J. S. Henslow, 24 Nov 1832 (Burkhardt and Smith 1985: 280). The toad also made it into Researches (Darwin 1839: 114-115); see Milton (1674: 4: 798).

${ }^{13}$ Darwin's brother Erasmus introduced them to each other over tea in 1838. Darwin read all of Carlyle's works. In a letter from 1840 Darwin's wife Emma wrote: "I have been reading Carlyle, like all the rest of the world ... Charles keeps on reading and abusing him" (Litchfield 1915: 52). In his "Books read" notebook, Darwin judged Hero-worship to be of "moderate" quality (Burkhardt and Smith 1988: 462).

14 "His mind seemed to me a very narrow one", wrote Darwin (1887: 1: 78) about Carlyle, "even if all branches of science, which he despised, were excluded" (note the tree reference).

15 A. Einstein to Kamerlingh-Onnes's widow, 25 February 1926; Einstein Archive 14-389.

\section{REFERENCES}

ARCHIBALD, J. D., 2009 Edward Hitchcook's pre-Darwinian (1840) 'tree of life'. Journal of the history of biology 42: $561-592$.

ARIEW, R., 1992 Descartes and the tree of knowledge. Synthese 92: 101-116.

AUGIER, A., 1801 Essai d'une nouvelle classification des vegetaux. Lyon.

AUROUX, S., 1990 Representation and the place of linguistic change before comparative grammar, pp. 213-238 in DE MAURO, T. and FORMIGARI, L. (editors), Leibniz, Humboldt, and the origins of comparativism. Amsterdam \& Philadelphia.

BAPTESTE, E., O’MALLEY, M. A., BEIKO, R. G., ERESHEFSKY, M., GOGARTEN, J. P., FRANKLIN-HALL, L., LAPOINTE, F. J., DUPRÉ, J., DAGAN, T., BOUCHER, Y. and MARTIN, W., 2009 Prokaryotic evolution and the tree of life are two different things. Biology direct 4 (34).

BARRETT, P., 1974 The Sedgwick-Darwin geologic tour of North Wales. Proceedings of the American Philosophical Society 118 (2): 146-164.

BARRETT, P. H., GAUTREY, P. J., HERBERT, S., KOHN, D. and SMITH, S. (editors), 1987 Charles Darwin's notebooks, 1836-1844. Cambridge.

BEER, G., 1985 Darwin's reading and the fictions of development, pp. 543-588 in KOHN, D. (editor), The Darwinian heritage. Princeton \& Guildford. 
BEER, G., 2009 Darwin's plots: evolutionary narrative in Darwin, George Eliot and nineteenth-century fiction. Cambridge \& New York.

BONNET, C., 1764 Contemplation de la nature. Volume 1. Amsterdam.

BONNET, C., 1766 The contemplation of nature. Volume 1. London.

BOUQUET, M., 1995 Exhibiting knowledge: the trees of Dubois, Haeckel, Jesse and Rivers at the Pithecanthropus centennial exhibition, pp. 31-56 in STRATHERN, M. (editor), Shifting contexts: transformations in anthropological knowledge. London \& New York.

BOUQUET, M., 1996 Family trees and their affinities: the visual imperative of the genealogical diagram. Journal of the Royal Anthropological Institute 2 (1): 43-66.

BREDEKAMP, H., 2005 Darwins Korallen: Die frühen Evolutionsdiagramme und die Tradition der Naturgeschichte. Berlin.

BRINK-ROBY, H., 2009 Natural representation: diagram and text in Darwin's On the origin of species. Victorian studies 51 (2): 247-273.

BUFFON, G. L. L. and DAUBENTON, L. J. M., 1766 Histoire naturelle. Volume 14. Paris.

BURKHARDT, F., PORTER, D. M., BROWNE, J. and RICHMOND, M. (editors), 1993 The correspondence of Charles Darwin. Volume 8. Cambridge.

BURKHARDT, F. and SMITH, S. (editors), 1985 The correspondence of Charles Darwin. Volume 1. Cambridge.

BURKHARDT, F. and SMITH, S. (editors), 1986 The correspondence of Charles Darwin. Volume 2. Cambridge.

BURKHARDT, F. and SMITH, S. (editors), 1988 The correspondence of Charles Darwin. Volume 4. Cambridge.

BURKHARDT, F. and SMITH, S. (editors), 1990 The correspondence of Charles Darwin. Volume 6. Cambridge.

BYRON, G. G., 1817 Manfred, a dramatic poem. London.

CARLYLE, T., 1841 On heroes, hero-worship, and the heroic in history. London.

CHANCELLOR, G. and VAN WYHE, J. (editors), 2009 Charles Darwin's notebooks from the voyage of the "Beagle". Cambridge.

CUMMING, J., 1857 Consolations, or, leaves from the tree of life. London.

DARWIN, E., 1794 Zoonomia; or, the laws of organic life. Volume 1. London.

DARWIN, C., 1839 Narrative of the surveying voyages of His Majesty's Ships Adventure and Beagle between the years 1826 and 1836. Volume 3. London.

DARWIN, C., 1858 Abstract of a letter ... to Prof. Asa Gray, Boston, U.S., dated Down, September 5th, 1857. Journal of the proceedings of the Linnean Society of London, zoology 3 (20 August): 50-53.

DARWIN, C., 1859 On the origin of species. London.

DARWIN, C., 1871 The descent of man, and selection in relation to sex. London.

DARWIN, C., 1872 The expression of the emotions in man and animals. London.

DARWIN, F. (editor), 1887 The life and letters of Charles Darwin. London. 3 volumes.

DARWIN, F. (editor), 1909 The foundations of the origin of species. Two essays written in 1842 and 1844. Cambridge.

DELEUZE, G. and GUATTARI, F., 1980 Mille plateaux. Paris.

DESCARTES, R., 1647 Preface. Les principes de la philosophie. Paris.

DESMOND, A. and MOORE, J., 2009 Darwin's sacred cause: race, slavery and the quest for human origins. London.

DOOLITTLE, W. F., 1999 Phylogenetic classification and the universal tree. Science 284: 2124-2129.

DOOLITTLE, W. F., 2000 Uprooting the tree of life. Scientific American 282 (2): 90-95.

DOOLITTLE, W. F., 2009 The practice of classification and the theory of evolution, and what the demise of Charles Darwin's tree of life hypothesis means for both of them. Philosophical transactions of the Royal Society 364: 2221-2228.

DOOLITTLE, W. F., 2010 The attempt on the life of the tree of life: science, philosophy and politics. Biology and philosophy 25 (4): 455-473.

FITZROY, R., 1839 Narrative of the surveying voyages of His Majesty's Ships Adventure and Beagle between the years 1826 and 1836. Volume 2. London. 
GOETHE, J. W. von, 1808 Faust: eine Tragödie. Tübingen.

GOETHE, J. W. von, 1833 Faust: a dramatic poem. London.

GOULD, S. J., 1997 Ladders and cones: constraining evolution by canonical icons, pp. 37-67 in SILVERS, R. B. (editor), Hidden histories of science. London.

GRAY, A., 1874 Charles Robert Darwin. American naturalist 8 (8): 475-479.

GRUBER, H. E., 1978 Darwin's “Tree of Nature” and other images of wide scope, pp. 120-140 in WECHSLER, J. (editor), On aesthetics in science. Cambridge, Massachusetts.

HACKING, I., 2007 Trees of logic, trees of Porphyry, pp. 219-261 in HEILBRON, J. L. (editor), Advancements of learning: essays in honour of Paolo Rossi. Florence.

HELLSTRÖM, N. P., 2011 The tree as evolutionary icon: TREE in the Natural History Museum, London. Archives of natural history 38 (1): 1-17.

HITCHCOOK, E., 1840 Elementary geology. Amherst.

HUXLEY, T. H., 1887 On the reception of the 'Origin of Species', pp. 179-204 in DARWIN, F. (editor), The life and letters of Charles Darwin. Volume 2. London.

JAMES, E. O., 1966 The tree of life: an archaeological study. Leiden.

JAMES, E. O., 1968. The tree of life. Folklore 79 (4): 241-249.

JOHNSON, J. R., 1961 The tree of Jesse window of Chartres: Laudes regiae. Speculum 36 (1): 1-22.

KENNEDY, J., 1854 The root and the fruits of the tree of life. A help to lay-agents and scripture-readers. London.

KEYNES, R. D. (editor), 1988 Charles Darwin's 'Beagle' diary. Cambridge.

KLAPISCH-ZUBER, C., 2000 L'ombre des ancêtres: essai sur l'imaginaire médiéval de la parenté. Paris.

KLAPISCH-ZUBER, C., 2007 The tree, pp. 293-314 in MOLHO, A., RAMADA CORTO, D. and KONIORDOS, N. (editors), Finding Europe: discourses on margins, communities, images ca. 13th - ca. 18th centuries. New York \& Oxford.

LAMARCK, J. B., 1809 Philosophie zoologique. Volume 2. Paris.

LINNAEUS, C., 1735 Systema naturae. Leiden.

LITCHFIELD, H. (editor), 1915 Emma Darwin: a century of family letters, 1792-1896. Volume 2. London.

LYELL, C., 1830-1833. Principles of geology. London. 3 volumes.

MILTON, J., 1674 Paradise lost. London.

MOUCHON, P., 1780 Table analytique et raisonnée de l'Encyclopédie de Diderot et d'Alembert. Volume 1. Paris.

O'MALLEY, M. A., MARTIN, W. and DUPRÉ, J. (editors), 2010 The tree of life: introduction to an evolutionary debate. Biology and philosophy 25 (4): 441-453.

OREN, A. and PAPKE, R. T. (editors), 2010 Molecular phylogeny of microorganisms. Hethersett.

PALLAS, P. S., 1766 Elenchus zoophytorum. The Hague.

RAGAN, M. A., 2009 Trees and networks before and after Darwin. Biology direct 4 (43).

SCHAMA, S., 2004. Landscape and memory. London.

SECORD, J. A., 1981 Nature's fancy: Charles Darwin and the breeding of pigeons. Isis 72 (2): 163-186.

SLOAN, P. R., 2006 Kant on the history of nature: the ambiguous heritage of the critical philosophy for natural history. Studies in history and philosophy of biological and biomedical sciences 37: 627-648.

SHEPHEARD, H., 1864 The tree of life; or, redemption, and its fruits in grace and glory. London.

SMITH, J., 1860 Fruit from the tree of life, or, meat and medicine for the soul. Halifax \& London.

SPEED, J., 1611 The genealogies recorded in the sacred scriptures, according to euery family and tribe, with the line of our Sauiour Iesus Christ, obserued from Adam to the blessed Virgin Mary. London.

SPEED, J., 1817 Scripture genealogy from Adam to Christ. London.

SPEDDING, J., ELLIS, R. L. and HEATH, D., 1857 The works of Francis Bacon. Volume 3. London.

SPEDDING, J., ELLIS, R. L. and HEATH, D., 1858 The works of Francis Bacon. Volume 4. London.

STAUFFER, R. C. (editor), 1975 Charles Darwin's natural selection; being the second part of his big species book written from 1856 to 1858 . London \& New York. 
STEVENS, P. F., 1983 Augustin Augier's “Arbre Botanique” (1801), a remarkable early botanical representation of the natural system. Taxon 32 (2): 203-211.

VOSS, E. G., 1952 The history of keys and phylogenetic trees in systematic biology. Journal of the scientific laboratories of Denison University 43: 1-25.

VOSS, J., 2009 Darwins Bilder: Ansichten der Evolutionstheorie, 1837-1874. Frankfurt am Main.

WATSON, A., 1934 The early iconography of the tree of Jesse. London.

WRIGHT, G. H. von, 1993 The tree of knowledge and other essays. Leiden, New York \& Köln.

Received 1 July 2011. Accepted 16 December 2011. 